\title{
Use of Fatty Acid Methyl Ester Profiles to Compare Copper-Tolerant and Copper-Sensitive Strains of Pantoea ananatis
}

\author{
C. Nischwitz, R. Gitaitis, H. Sanders, D. Langston, B. Mullinix, R. Torrance, G. Boyhan, and L. Zolobowska
}

First, second, third, and fourth authors: Department of Plant Pathology, and fifth author: Experimental Statistics, University of Georgia, Tifton 31793, sixth author: Tattnall County Extension Coordinator, University of Georgia, Reidsville 30453, seventh author: Department of Horticulture, University of Georgia, Statesboro 30460; and eighth author: Laboratoire de nutrition azotée des plantes, INRA, Route de Saint Cyr, 78026 Versailles, France. Accepted for publication 10 May 2007.

\begin{abstract}
Nischwitz, C., Gitaitis, R., Sanders, H., Langston, D., Mullinix, B. Torrance, R., Boyhan, G., and Zolobowska, L. 2007. Use of fatty acid methyl ester profiles to compare copper-tolerant and copper-sensitive strains of Pantoea ananatis. Phytopathology 97:1298-1304.

A survey was conducted to evaluate differences in fatty acid methyl ester (FAME) profiles among strains of Pantoea ananatis, causal agent of center rot of onion (Allium cepa), isolated from 15 different onion cultivars in three different sites in Georgia. Differences in FAME composition were determined by plotting principal components (PCs) in twodimensional plots. Euclidean distance squared $\left(\mathrm{ED}^{2}\right)$ values indicated a high degree of similarity among strains. Plotting of PCs calculated from $P$. ananatis strains capable of growing on media amended with copper sulfate pentahydrate $(200 \mu \mathrm{g} / \mathrm{ml})$ indicated that copper-tolerant strains grouped into tight clusters separate from clusters formed by wild-type strains. However, unlike copper-sensitive strains, the copper-tolerant strains tended to cluster by location. A total of 80,60 , and $73 \%$ of the strains from Tift1, Tift2, and Tattnall, respectively, exhibited either confluent growth or partial growth on copper-amended medium. However,

$(200 \mu \mathrm{g} / \mathrm{ml})$ and maneb $(40 \mu \mathrm{g} / \mathrm{ml})$. When copper-tolerant clones were analyzed and compared with their wild-type parents, in all cases the plotting of PCs developed from copper-tolerant clones formed tight clusters separate from clusters formed by the parents. Eigenvalues generated from these tests indicated that two components provided a good summary of the data, accounting for 98,98 , and $96 \%$ of the standardized variance for strains Pna 1-15B, Pna 1-12B, and Pna 2-5A, respectively. Furthermore, feature 4 (cis-9-hexadecenoic acid/2-hydroxy-13-methyltetradecanoic acid) and feature 7 (cis-9/trans-12/cis-7-octadecenoic acid) were the highest or second highest absolute values for PC1 in all three strains of the parents versus copper-tolerant clones, and hexadecanoic acid was the highest absolute value for PC2 in all three strains. Along with those fatty acids, dodecanoic acid and feature 3 (3-hydroxytetradecanoic acid/14-methylpentadecenoic acid) also had an impact on the differences observed between copper-sensitive parents and copperresistant mutants. Finding these changes in bacterial fatty acid composition could lead to the development of a laboratory assay to identify copper-tolerant strains using gas chromatography as well as providing clues to further elucidate the mode of action of copper tolerance.
\end{abstract} all strains were sensitive to a mixture of copper sulfate pentahydrate
Center rot of onion, caused by Pantoea ananatis (Serrano) Mergaert, was first observed on Vidalia sweet onion in Georgia late in the season (May) in 1997 and accounted for 100\% loss in some fields (22). The identity of the bacterium was confirmed by biochemical and physiological tests, fatty acid methyl ester (FAME) analysis (Microbial ID Inc., Newark, DE), a BLAST search of a sequence from the $16 \mathrm{~S}$ gene, and BIOLOG (BIOLOG, Hayward, CA) $(22,24,25)$. In addition to onion, the bacterium has been reported to infect Eucalyptus (Eucalyptus sp.), honeydew melon (Cucumis melo), muskmelon (C. melo var. reticulatus), pineapple (Ananas comosus), Sudangrass (Sorghum bicolor subsp. drummondii), sugarcane (Saccharum sp.), and rice (Oryza sp.) $(3,8,9,15,19,34,64)$. The bacterium also has been associated with the condition known as graywall of tomato (59) and some strains (formerly Erwinia uredovora) have been associated with infections of Puccinia graminis (52).

Symptoms in onion generally include white streaks with watersoaked margins running the length of the leaf. In time, streaks may darken to a light-brown color, gray, or remain white. Frequently, initial infections develop only on one or two leaves in the center of the plant. Severely infected plants display wilting and bleaching of all leaves. As infections proceed down the leaf

Corresponding author: C. Nischwitz; E-mail address: cnisch@uga.edu

doi:10.1094/PHYTO-97-10-1298

(c) 2007 The American Phytopathological Society and neck, the bacteria may invade bulb tissues. Bulb interiors become diseased and discolored and, frequently, are colonized by secondary microbes that result in liquefaction of tissue and the production of a foul odor. Attempts to harvest onion bulbs in that condition result in the leaves tearing away from the necks and the bulbs remaining on the ground.

A similar disease of onion, caused by Pantoea agglomerans (syn. Erwinia herbicola), was reported from South Africa in 1981 (28). P. agglomerans and P. ananatis are closely related (39) and the seed of the onion cultivar on which center rot was first observed was produced in South Africa; therefore, we speculated that $P$. ananatis may have been introduced into Georgia via seedborne contamination (63). The seedborne nature of the disease was confirmed by using an immunomagnetic separation polymerase chain reaction (IMS-PCR) technique to concentrate the bacteria, remove the PCR inhibitors associated with onion seed, and amplify the bacterial DNA from the intergenic transcribed spacer (ITS) region between the $16 \mathrm{~S}$ and $23 \mathrm{~S}$ rDNA genes (63). Seedborne inoculum may not be the only potential source of inoculum, because $P$. ananatis was found to be endemic to Georgia, and evidence from the UGA Coastal Plain Experiment Station (CPES) culture collection suggests that the bacterium was present in Georgia prior to the 1997 epidemic (24). Furthermore, the bacterium was detected as an epiphyte on $>20$ weed species growing in a $250-\mathrm{km}$ transect surveyed between Toombs, Tift, and Terrell Counties, GA. The bacterium was a major component of the gut microflora of tobacco thrips (Frankliniella fusca) (65). Further 
study demonstrated that thrips collected from onion, peanut, and various weeds could transmit $P$. ananatis to healthy onion (26).

The role that each inoculum source plays in onion epidemics is unclear. Consequently, to learn more about the epidemiology of this disease, we investigated a natural outbreak of center rot in a cultivar trial conducted at three different locations in Georgia. Others have used fatty acid analysis in multiphasic studies characterizing bacteria or to track strains in epidemiologic studies $(41,55,61,62)$. Using fatty acid analysis, Baird et al. (4) demonstrated that ecotypes and anastomosis groups of Rhizoctonia solani clustered into groups according to their geographic origin. Obradovic et al. (45) used fatty acid analysis as part of a multiphasic study that characterized different strains of Xanthomonas causing bacterial spot of pepper and tomato in Serbia. Similarly, Dookun et al. (18) used fatty acid profiles to characterize variation among strains of Xanthomonas campestris pv. vasculorum. In another study, phospholipid fatty acids were helpful in tracking the succession of microbial communities in composted dairy waste (10). Leonard et al. (33) and Birnbaum et al. (7) used the MIDI system to characterize methicillin-resistant strains of Staphylococcus aureus responsible for nosocomial infections and the typing of coagulase-negative staphylococci strains, respectively. Gitaitis et al. (21) demonstrated that fatty acid analysis was helpful with decision making in regard to the issuance of phytosanitary certificates for the export of tomato transplants. Other examples of using fatty acid analysis in epidemiologic studies include the monitoring of bacterial population changes in drinking water (44), changes in soil microbial communities associated with changes in salinity or alkalinity (49), changes in soil microbial communities associated with different agriculturally managed soils (67), and changes in soil microbial communities associated with degree of heavy metal pollution (50).

Hence, we used fatty acid analysis to characterize strains of $P$. ananatis isolated from 15 different onion cultivars grown in a replicated trial at three different geographic locations in Georgia. Our goal was to determine whether fatty acid profiles could be used to identify sources of inoculum, methods of dissemination, origin of strains, strain aggressiveness, copper tolerant strains, and other aspects related to the epidemiology of center rot.

\section{MATERIALS AND METHODS}

Fifteen cultivars of Vidalia sweet onion were seeded in prepared beds in September 1998. Seedlings were transplanted 12, 18, and 19 November, 1998 at sites in Tattnall County, and in Chula and the CPES Horticulture Farm in Tift County, respectively. Onion plants were transplanted in four rows on a $1.8-\mathrm{m}$ bed with $30.5 \mathrm{~cm}$ between adjacent rows and $12.7 \mathrm{~cm}$ between plants in the same row. Plots were $15.2 \mathrm{~m}$ in length and contained $\approx 480$ plants per plot. Treatments were arranged in a completely randomized design with three replications. Prior to harvest, incidence of center rot was assessed by counting the number of diseased plants per plot.

Bacteria recovered from diseased onion were isolated on King's medium B (KMB) and, after purification, were stored in $15 \%$ glycerol at $-80^{\circ} \mathrm{C}$ for long-term storage. Bacteria were isolated from three plants of each cultivar at each location $(n=135)$. Bacteria were characterized by colony color on trypticase soy broth agar (TSBA), gram reaction, oxidase reaction, oxidativefermentative utilization of glucose, indole production, presence of nitrate reductase, FAME profiles, tolerance to copper at $50 \mu \mathrm{g} / \mathrm{ml}$ amended in nutrient agar (NA) as copper sulfate pentahydrate at $200 \mu \mathrm{g} / \mathrm{ml}$ and tolerance to copper at $50 \mu \mathrm{g} / \mathrm{ml}$ and maneb at $40 \mu \mathrm{g} / \mathrm{ml}$ amended in NA.

FAME profiles were obtained by using an HP Model 5890A gas chromatograph (GC) (Hewlett-Packard Company, Palo Alto, CA) equipped with a phenyl methyl silicone fused silica capillary column, $2 \mathrm{~m}$ by $0.2 \mathrm{~mm}$, connected to the injection port and the flame ionization detector. Hydrogen and nitrogen were used as the carrier and make-up gases, respectively. Ultraclean air was used to support the flame. FAME were extracted from 24- to 26-h bacterial cultures incubated at $28^{\circ} \mathrm{C}$ on TSBA medium. A loopful of bacteria harvested from the third quadrant of TSBA plates was added to $1 \mathrm{ml}$ of sodium hydroxide solution $(15 \%$ [wt/vol] $\mathrm{NaOH}$ in $50 \%$ [vol $/ \mathrm{vol}]$ aqueous methanol) in screw-cap tubes and saponified. Tubes were mixed for $10 \mathrm{~s}$ using a vortex stirrer. Samples were heated for $5 \mathrm{~min}$ at $100^{\circ} \mathrm{C}$ in a hot-water bath and then stirred on a vortex mixer for $10 \mathrm{~s}$. Samples were returned to the hot-water bath and were saponified for $25 \mathrm{~min}$ at $100^{\circ} \mathrm{C}$. After cooling, samples were acidified with $2 \mathrm{ml}$ of $6 \mathrm{~N} \mathrm{HCl}-$ methanol solution $(1.18: 0.85, \mathrm{vol} / \mathrm{vol})$ and incubated at $80^{\circ} \mathrm{C}$ for $10 \mathrm{~min}$. After cooling, FAME were extracted with a $1.25-\mathrm{ml}$ mixture of hexane and methyl-tert butyl ether (1:1). After gentle mixing endover-end for $10 \mathrm{~min}$, samples were kept stationary to allow separation of the organic and aqueous phases. A Pasteur pipette was used to remove and discard the lower aqueous phase after a clear line of separation between the two phases was observed. The remaining top, organic phase was washed by gentle mixing for 5 min with $3 \mathrm{ml}$ of a $1.2 \%$ sodium hydroxide solution. Samples were kept stationary to allow separation of the organic and aqueous phases. After a clear line of separation between the two phases was observed, a Pasteur pipette was used to remove the top two-thirds of the organic phase, which was transferred to a GC vial. GC run conditions were according to the Sherlock Microbial Identification System (SMIS) (Microbial ID, Inc.). Oven temperatures ramped from 170 to $270^{\circ} \mathrm{C}$ at $5^{\circ} \mathrm{C} / \mathrm{min}$. Following the analysis of each sample, the oven temperature was increased to $300^{\circ} \mathrm{C}$ to clean the column during a 2-min hold period. Before the analysis of samples, the GC was calibrated twice with a commercial FAME mix (Microbial ID, Inc.). The GC was recalibrated after every 10 samples that were run. In all cases, the first sample of each run was Stenotrophomonas maltophilia, which was used as a standard to verify the performance of SMIS in identifying the samples. The principal component analysis (PCA) option of the SMIS program was used to plot principal components (PCs) 1, 2, and 3 to compare subgroups of strains of $P$. ananatis isolated from 15 different onion cultivars, isolated from the three different geographic sites and differing in tolerance to copper. Euclidean distance squared $\left(\mathrm{ED}^{2}\right)$ values were calculated according to the manufacturer's recommendation (Microbial ID, Inc.). Briefly, after forming a line around obvious clusters on the PC plots, lines were extrapolated from the top and bottom edges to the ordinate and from the left and right edges to the abscissa. The difference between the two points where the lines intersected with the ordinate were multiplied by the difference between the two points where the lines intersected with the abscissa. The resulting product was the $\mathrm{ED}^{2}$.

After the analysis of the initial results, 10 copper-sensitive strains of $P$. ananatis from the Tattnall County site were purified by three successive single-colony transfers and were stored as Pna 1-01-C, Pna 1-02-A Pna 1-03-A, Pna 1-07-B, Pna 1-10-B, Pna 112-B, Pna 1-15-B, Pna 2-05-A, Pna 2-08-A, and Pna 2-11-C. The strains were isolated from onion cvs. DP1032, DP1058, DP1063, Global 2012, Pegasus, Sweet Melody, Y33, Asgrow 6712, $F_{1}$, and Sweet Vidalia, respectively. The parent strains were incubated in nutrient broth at $28^{\circ} \mathrm{C}$ on a rotary shaker at $150 \mathrm{rpm}$ for $24 \mathrm{~h}$. After incubation, $40 \mathrm{ml}$ of the bacterial suspensions were centrifuged at 3,000 $\times g$ (where $g=$ relative centrifugal field) for $15 \mathrm{~min}$. The supernatant was discarded and the pellet was resuspended in $1.0 \mathrm{ml}$ of sterile phosphate-buffered saline $(0.01 \mathrm{M}$ $\mathrm{KH}_{1} \mathrm{PO}_{4}-\mathrm{K}_{2} \mathrm{HPO}_{4}, \mathrm{pH} 7.0$, and $0.85 \% \mathrm{NaCl}$ ). Aliquants of $1.0 \mathrm{ml}$ of the resuspended bacteria were spread on the surface of plates of NA amended with $\mathrm{CuSO}_{4} \cdot 5 \mathrm{H}_{2} \mathrm{O}$ at $200 \mu \mathrm{g} / \mathrm{ml}$ and were incubated at $28^{\circ} \mathrm{C}$. A developing colony on the copper-amended media was selected and transferred to another copper-amended plate of NA. Bacteria harvested from these plates were stored as 
copper-tolerant clones of the original parent strains and were labeled as Pna 1-01-C CuR , Pna 1-02-A ${ }^{\mathrm{CuR}}, \ldots$ and Pna 2-11- $\mathrm{C}^{\mathrm{CuR}}$, respectively. FAME profiles from three replications each of Pna 1-12-B, Pna 1-15-B, Pna 2-05-A, and their copper-tolerant clones were analyzed by PCA as described above. The data developed from the SMIS was transferred to SAS (SAS Institute Inc., Cary, NC) and eigenvalues were generated for PCA. The eigenvalues identified which fatty acids contributed most to PC1 and PC2. Furthermore, values for PC1 and PC2 generated for coppersensitive and copper-tolerant strains were analyzed by the General Linear Model (GLM) program (SAS Institute Inc.).

\section{RESULTS}

A total of 80,60 , and $73 \%$ of the $P$. ananatis strains from the Tift1, Tift2, and Tattnall research sites, respectively, exhibited

TABLE 1. Shorthand formulas and their corresponding systematic names of major fatty acids detected in Pantoea ananatis

\begin{tabular}{ll}
\hline Shorthand formula $^{\mathrm{a}}$ & \multicolumn{1}{c}{ Systematic name } \\
\hline $12: 0$ & Dodecanoic \\
14:0 & Tetradecanoic \\
$15: 0$ & Pentadecanoic \\
$2 \mathrm{OH} 14: 0$ & 2-Hydroxytetradecanoic \\
$3 \mathrm{OH} 14: 0$ & 3-Hydroxytetradecanoic \\
$2 \mathrm{OH}$ i15:0 & 2-Hydroxy 13-methyltetradecanoic \\
$\mathrm{i} 16: 1$ & 14-Methylpentadecenoic \\
$16: 1 \omega 7 \mathrm{c}$ & Cis-9 hexadecenoic \\
$16: 0$ & Hexadecanoic \\
cy17:0 & Delta-cis-9,10-methylene hexadecanoic \\
$17: 0$ & Heptadecanoic \\
$10 \mathrm{methyl} 17: 0$ & Anteiso-octadecanoic \\
$18: 1 \omega 9 \mathrm{c}$ & Cis-9 octadecenoic \\
$18: 1 \omega 12 \mathrm{t}$ & Trans-12 octadecenoic \\
$18: 1 \omega 7 \mathrm{c}$ & Cis-7 octadecenoic \\
$18: 0$ & Octadecanoic \\
\hline
\end{tabular}

a The shorthand designation uses the number of carbon atoms preceding a colon with the number after the colon representing the number of double bonds. If a double bond occurs, a $\omega$ is followed by a number representing the position of the double bond when counting from the carboxyl end of the carbon chain. The symbols $\mathrm{c}$ and $\mathrm{t}$ represent the cis and trans isomers, respectively. The prefixes cy, a, and $\mathrm{i}$ are for cyclopropane, anteiso, and iso branching, respectively. An $\mathrm{OH}$ indicates a hydroxyl group at the 2 or 3 position from the carboxyl end.

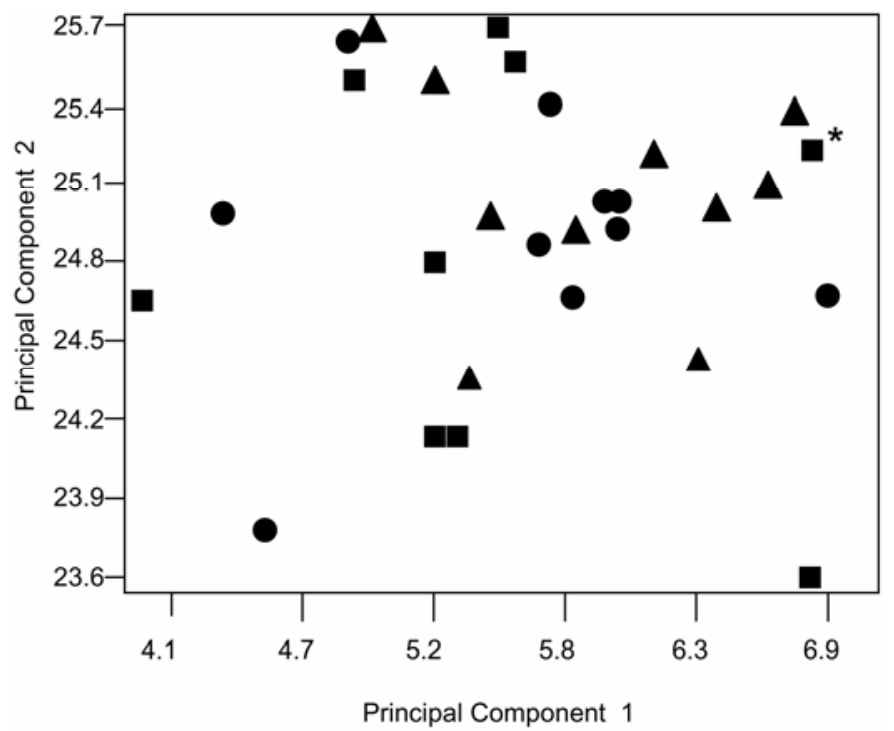

Fig. 1. Principal component 1 versus principal component 2 of data set generated from fatty acid profiles of copper-sensitive strains of Pantoea ananatis from the Tift County $1(\boldsymbol{\square})$, Tift County $2(\boldsymbol{\Delta})$, and Tattnall County $(\boldsymbol{O})$ sites; * indicates multiple data points at the same location. either confluent growth or partial growth on the copper-amended medium. However, all of the strains were sensitive to a mixture of copper $(50 \mu \mathrm{g} / \mathrm{ml})$ and maneb $(40 \mu \mathrm{g} / \mathrm{ml})$.

The SMIS correctly identified all 20 strains as $P$. ananatis (mean similarity index value of 0.91 ) based on FAME profiles of representative copper-sensitive strains and copper-tolerant strains. The systematic names and their shorthand designations of the fatty acids found in $P$. ananatis are listed in Table 1.

When PCA was run on FAME profiles from 30 strains of $P$. ananatis from the three locations, it failed to produce any patterns that would cluster strains due to relationship with either cultivar or geographic location (Fig. 1). However, copper-tolerant strains from these locations tended to cluster by geographic location when PC1 was plotted against PC2 (Fig. 2). The standard deviation for the $\mathrm{x}$ - and $\mathrm{y}$-axes were 2.01 and 0.94 , respectively, and the $\mathrm{ED}^{2}$ value was 7.5. Plotting PC1 (x-axis) against PC2 (yaxis) for both copper-sensitive and copper-tolerant strains from the Tattnall County site produced a cluster composed entirely of copper-sensitive strains and another cluster of primarily coppertolerant strains (Fig. 3). The standard deviations for the $\mathrm{x}-$ and $\mathrm{y}-$ axes were 1.28 and 0.91 , respectively, and the $\mathrm{ED}^{2}$ value was 6.3 . A similar pattern of clustering occurred for all three strains when PC1 was plotted against PC2 for the three copper-sensitive parents and their copper-tolerant clones (Fig. 4A to C). In the plot generated by Pna 1-12-B, the standard deviation for $\mathrm{x}=1.74$, the standard deviation for $\mathrm{y}=0.748$, and the $\mathrm{ED}^{2}=0.46$. (Fig. 4A). GLM analysis using SAS indicated that the PCs of the coppersensitive parents of Pna 1-12-B were significantly different $(P=$ 0.0001) from the PCs of the copper-tolerant clones. Based on the eigenvalues, 16:0, and feature seven, an isomer mix of (18:1 $\omega 9 \mathrm{c} / \omega 12 \mathrm{t} / \omega 7 \mathrm{c})$ were the highest contributors to PC1 and PC2, respectively, and accounted for $98 \%$ of the standardized variance. Features three (mixture of $3 \mathrm{OH}$ 14:0/i16:1) and four (16:1 $\omega 7 \mathrm{c} / 2 \mathrm{OH}$ i15:0) were the second highest contributors. When PCA was run for the data set after sequentially removing the lowest contributors one at a time, the above fatty acids plus 12:0 and 18:0 were necessary in a minimum profile in order for the spatial relationship between $\mathrm{PC} 1$ and $\mathrm{PC} 2$ not to change. In addition, 12:0, feature three, and feature seven correlated to PC1 values in the full profile as well as the reduced profiles when profiles were reduced by values that contributed the least based on absolute value or reduced by those that didn't alter signs of major contributors of PC1 and PC2 when analyzed by PC1.

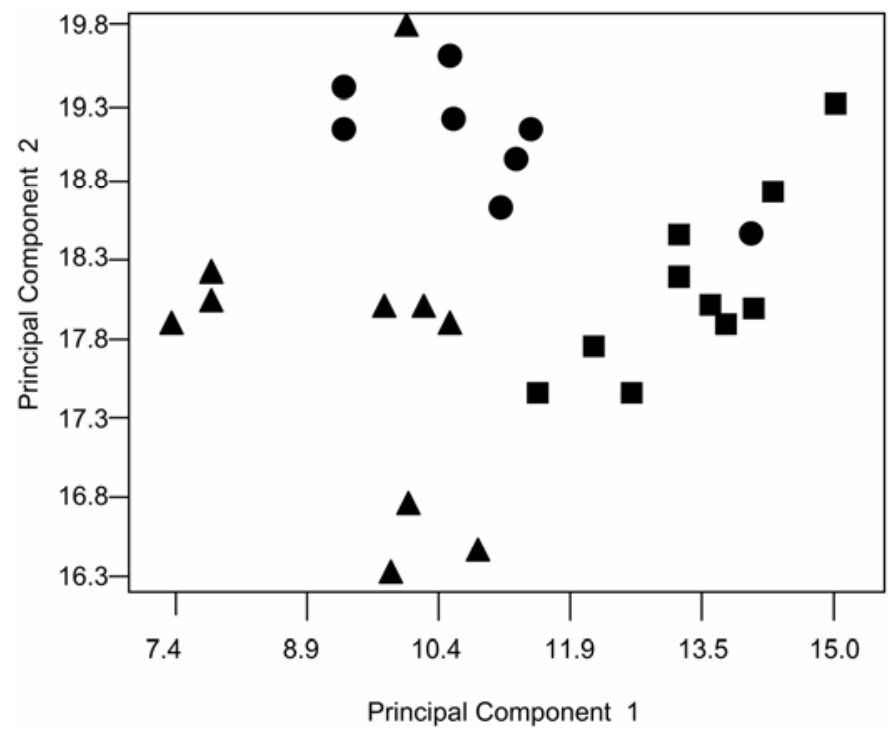

Fig. 2. Principal component 1 versus principal component 2 of data set generated from fatty acid profiles of copper-tolerant strains of Pantoea ananatis from the Tift County $1(\boldsymbol{\square})$, Tift County $2(\mathbf{\Delta})$, and Tattnall County (O) sites. 
In the plot generated by Pna 1-15-B, the standard deviation for $\mathrm{x}=1.54$, the standard deviation for $\mathrm{y}=0.821$, and the $\mathrm{ED}^{2}=2.5$ (Fig. 4B). GLM analysis using SAS indicated that the PCs of the copper-sensitive parents of Pna 1-15-B were significantly different $(P=0.0001)$ from the PCs of the copper-tolerant clones. Based on the eigenvalues, 16:0, and feature four, an isomer mix of $16: 1 \omega 7 \mathrm{c} / 2 \mathrm{OH}$ i15:0, were the highest contributors to $\mathrm{PC} 1$ and PC2, respectively, and accounted for $98 \%$ of the standardized variance. Feature seven (isomer mix of 18:1 $\omega 9 \mathrm{c} / \omega 12 \mathrm{t} / \omega 7 \mathrm{c}$ ) and cy 17:0 were the second highest contributors to PC1 and PC2. When PCA was run for the data set for Pna 1-15-B after sequentially removing the lowest contributors one at a time, the same

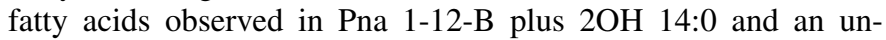
identified fatty acid with an equivalent chain length of 13.96 were necessary in a minimum profile in order for the spatial relationship between PC1 and PC2 not to change.

In the plot generated by Pna 2-05-A, the standard deviation for $\mathrm{x}=1.795$, the standard deviation for $\mathrm{y}=0.783$, and the $\mathrm{ED}^{2}=4.2$ (Fig. 4C). GLM analysis using SAS indicated that the PCs of the copper-sensitive parents of Pna 2-05-A were significantly different $(P=0.0001)$ from the PCs of the copper-tolerant clones. Feature four $(16: 1 \omega 7 \mathrm{c} / 2 \mathrm{OH}$ i15:0) and 16:0 were the highest contributors to PC1 and PC2, respectively, and accounted for $96 \%$ of the standardized variance. Both $\mathrm{PC} 1$ and $\mathrm{PC} 2$ of the coppersensitive parents were significantly different $(P=0.0001)$ from PC1 and PC2 of the copper-tolerant clones. Feature seven (18:1 $\omega 9 \mathrm{c} / \omega 12 \mathrm{t} / \omega 7 \mathrm{c})$ and $2 \mathrm{OH} 14: 0$ were the second highest contributors to PC1 and PC2.

When PCA was run for the data set for Pna 2-05-A after sequentially removing the lowest contributors one at a time, except for 18:0 the same fatty acids observed in Pna 1-12-B were necessary in a minimum profile in order for the spatial relationship between PC1 and PC2 not to change.

\section{DISCUSSION}

The role of copper in bacterial growth and survival is complex. Copper is essential for the function of superoxide dismutases, cytochrome $c$ oxidase, and many respiratory and metabolic enzymes, especially the enzymes that utilize dioxygen or reactive oxygen that mediate intracellular signaling cascades $(42,43,48)$.

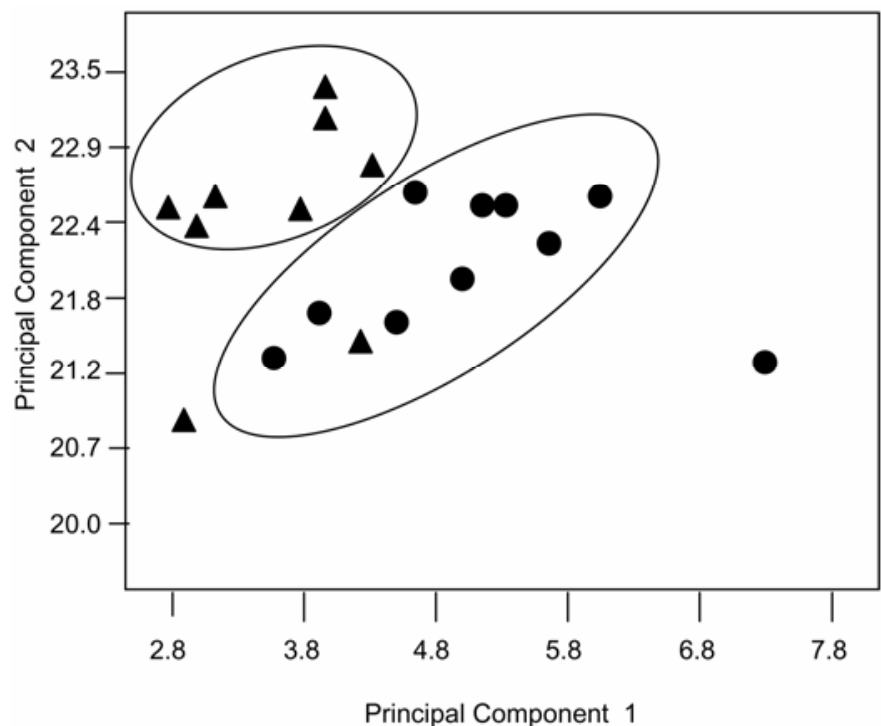

Fig. 3. Principal component 1 versus principal component 2 of data set generated from fatty acid profiles of copper-sensitive $(\boldsymbol{\Delta})$ and copper-tolerant $(\mathbf{O})$ strains of Pantoea ananatis from the Tattnall County site. Cluster of coppersensitive strains is significantly different $(P=0.001$, Proc GLM) from the cluster of copper tolerant strains.
On the other hand, when present in excess, copper is extremely toxic and can lead to loss of cell function and death. The latter quality has been why copper-containing pesticides have been recommended as a management tool for plant diseases since the first observation in the mid-eighteenth century that copper sulfate controlled stinking smut of wheat (31). In the nineteenth century, astute observations by Millardet led to the development of a combination of copper sulfate and lime (Bordeaux mixture) to control downy mildew of grape (31). Variations and advances in the formulation of copper compounds have been used since to
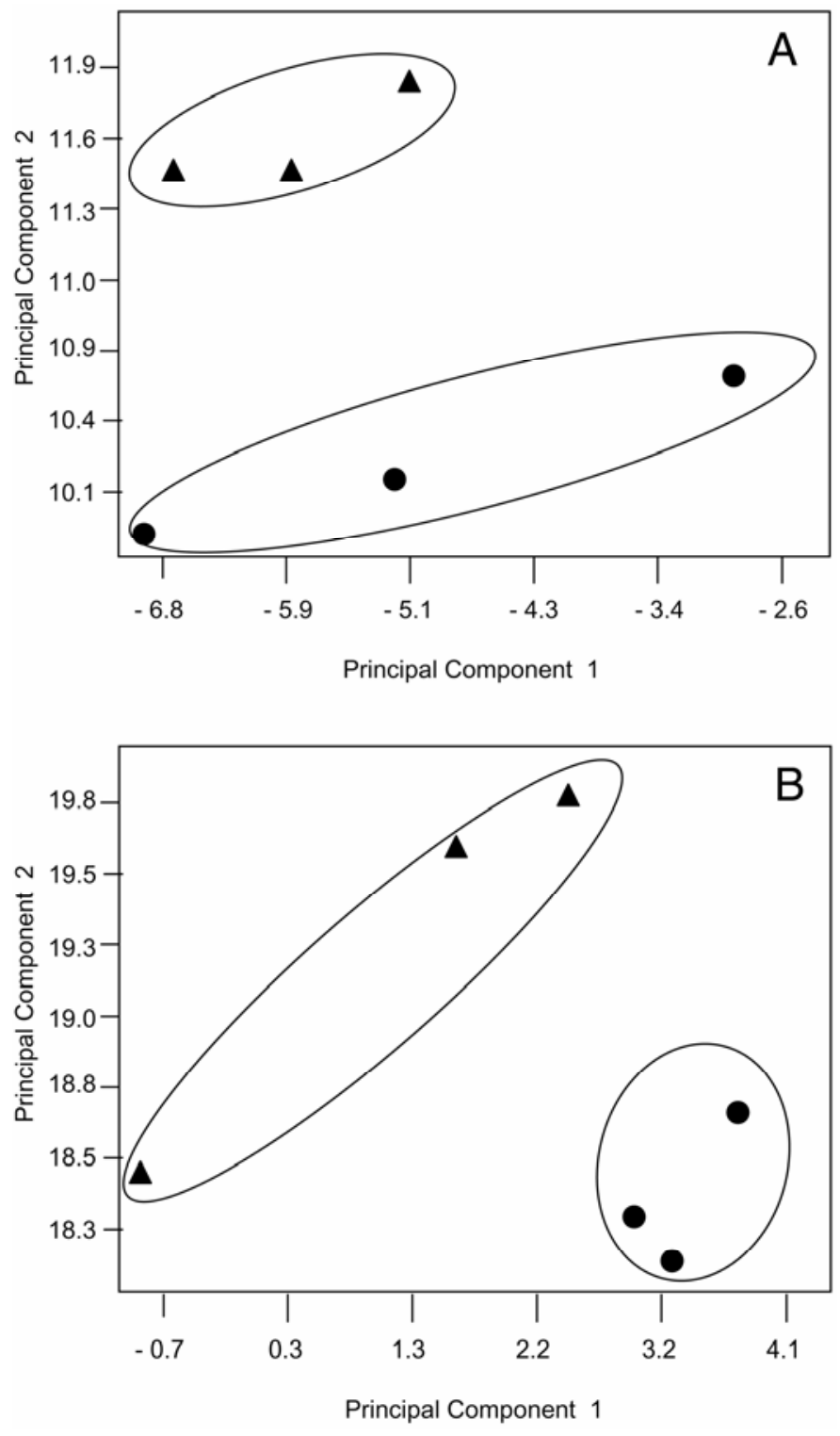

Fig. 4. A, Principal component 1 versus principal component 2 of data set generated from fatty acid profiles of three replications of the copper-sensitive parent strain (Pna 1-15B) $(\mathbf{\Delta})$ and three replications of the copper-tolerant clone (Pna 1-15B $\left.\mathrm{B}^{\mathrm{CuR}}\right)(\mathbf{)})$ of Pantoea ananatis from the Tattnall County site. Cluster of copper-sensitive parents is significantly different $(P=0.001$, Proc GLM) from the cluster of copper tolerant clones. B, Principal component 1 versus principal component 2 of data set generated from fatty acid profiles of three replications of the copper-sensitive parent strain (Pna 1-12A) ( $\mathbf{\Delta})$ and three replications of the copper-tolerant clone (Pna 1-12A $\left.{ }^{\mathrm{CuR}}\right)(\boldsymbol{O})$ of Pantoea ananatis from the Tattnall County site. Cluster of copper-sensitive parents is significantly different $(P=0.001$, Proc GLM) from the cluster of copper tolerant clones. C, Principal component 1 versus principal component 2 of data set generated from fatty acid profiles of three replications of the coppersensitive parent strain (Pna 2-5A) ( $\mathbf{\Delta}$ ) and three replications of the coppertolerant clone (Pna 2-5 $\mathrm{A}^{\mathrm{CuR}}$ ) $(-)$ of Pantoea ananatis from the Tattnall County site. Cluster of copper-sensitive parents is significantly different $(P=$ 0.001, Proc GLM) from the cluster of copper tolerant clones. 
control a multitude of fungal and bacterial diseases. Copper compounds have been used to effectively manage many different bacterial diseases over the decades $(12,16,17,46,58)$ and continue to be used for that purpose in the 21 st century $(32,40,53)$.

Copper-tolerant strains of bacteria have been found in a number of instances to reduce the efficacy of copper bactericides $(1,36$, $37,51,54,56)$. Because copper was not applied as a treatment in the field in our study, it is not known if the copper-tolerant strains of $P$. ananatis isolated are sufficiently tolerant to be considered resistant to field rates of recommended copper sprays. Furthermore, organic compounds can bind to and detoxify copper ions, causing an overestimation of copper tolerance when complex media are used for screening purposes $(6,38)$. Nonetheless, other studies have used copper-amended agar media successfully when the degree of copper tolerance was not the primary focus $(5,48,60)$. Further studies will have to be conducted to determine whether the copper tolerance observed in these $P$. ananatis strains is sufficient to make them resistant to commercial pesticides in the field. In other trials (unpublished), we observed that copper sprays were not as effective in controlling center rot as they are in controlling bacterial streak of onion, caused by Pseudomonas viridiflava (23). The reason for this difference is not known. One explanation could be the presence of copper-tolerant strains of Pantoea ananatis. However, it also could be because the dissemination and ingress of Pseudomonas viridiflava is by rain splashing, wind-blown aerosols, and entry into natural openings, making it more exposed to copper bactericides, whereas Pantoea ananatis can be transmitted by thrips directly into wounds created by thrips feeding (26).

As stated earlier, the goal of this study was to use fatty acid analysis and the SMIS to analyze multiple strains to determine whether there were differences in strains isolated from different cultivars or geographic locations in Georgia. Although no differences due to cultivar or locations were detected, differences in FAME were detected between copper-sensitive and copper-tolerant strains. The plotting of PCs clearly shows a spatial difference between copper-sensitive and copper-tolerant strains (Figs. 3 and 4). PCA is a statistical procedure that uses a covariance matrix to reduce a number of potentially correlated variables into a reduced number of uncorrelated variables named PCs. PCs are obtained by projecting the multivariate data vectors on the space spanned by the eigenvectors. PC1 accounts for as much of the variability in the data as possible, and each succeeding component accounts for as much of the remaining variability as possible. The SMIS program is useful for plotting PCs and visualizing relationships between species, subspecies, or strains. The $\mathrm{ED}^{2}$ values in PCA are a good indicator of different species when $>90$ and of subspecies when $>50$. In this study, $\mathrm{ED}^{2}$ values were low and ranged between 0.46 and 7.5, which confirmed that we were working with strains of $P$. ananatis. Unfortunately, the SMIS program does not reveal the eigenvalues it generates to formulate PC1, PC2, and $\mathrm{PC} 3$. Evaluation of the eigenvalues is necessary to assess what variables are contributing the most to the PCs. However, the eigenvalues can be obtained by transferring the data and running PCA in SAS and the variables can be identified.

When three different copper-sensitive parent strains were compared with their copper-tolerant clones, a similar shift in PC coordinates occurred for copper-tolerant strains when PC1 was plotted against PC2 (Fig. 4). Furthermore, when the eigenvalues were generated by SAS, a common pattern emerged; namely, that fatty acids $16: 0,16: 1 \omega 7 \mathrm{c} / 2 \mathrm{OH} \mathrm{i} 15: 0$, and $18: 1 \omega 9 \mathrm{c} / \omega 12 \mathrm{t} / \omega 7 \mathrm{c}$ were the highest or second highest contributors to PC1 and PC2 in all three strains when copper-sensitive parents were compared with their copper-tolerant clones. The fatty acids $2 \mathrm{OH} 14: 0,3 \mathrm{OH}$ 14:0/i16:1, and cy17:0 also were identified as high contributors to PC1 and PC2, but not for all strains. Frostegard et al. (20) found similar fatty acids changing in whole soil communities when the communities were experimentally exposed to different heavy metals. In their study, they used cadmium, copper, nickel, lead, and zinc, and did not differentiate between bacterial and fungal sources, let alone between bacterial species. As such, they found more fatty acids changing after exposure to the different heavy metals and by analyzing the entire soil microflora in bulk. However, Frostegard et al. (20) found that levels of 16:1 $\omega 5,16: 1 \omega 7 \mathrm{c}$, i16:0, cy17:0, and 18:2 $\omega 6$ were significantly altered in soils contaminated by heavy metals. Using a similar approach, Pennanen et al. (50) evaluated fatty acid composition of soil microbial communities along two gradients of heavy-metal-polluted soils in coniferous forests in Finland and Sweden. They concluded that altered fatty acid patterns were at least partly due to an altered, more metal-tolerant bacterial community. Changes were observed in a branched 18:0, branched 17:0, i16:0, i16:1, 18:2 $\omega 6$, and 20:4. Similar to Frostegard et al. (20), they evaluated entire soil communities and not individual species, and some of the fatty acids found altered in their study do not occur in $P$. ananatis. However, it is interesting to note that similar fatty acids, namely 16:0, $16: 1 \omega 7 \mathrm{c} / 2 \mathrm{OH}$ i15:0, 3OH 14:0/i16:1, cy 17:0, and $18: 1 \omega 9 \mathrm{c} / \omega 12 \mathrm{t} /$ $\omega 7 \mathrm{c}$, are associated with copper tolerance.

A number of reviews on the mode of action and genetic control of copper tolerance have been written $(11,13,14,42,66)$. Several mechanisms for copper tolerance have been suggested. In Escherichia coli and Enterococcus hirae, it has been suggested that copper tolerance is based on an efflux system where copper ions are actively pumped from the cell (66). It has been suggested that the uptake, intercellular storage, delivery, and efflux of copper is controlled by multiple cut genes (27). Another mechanism that has been suggested is the sequestering of copper by periplasmic and membrane proteins regulated by the cop operon $(13,14)$. It is believed that $\operatorname{cop} \mathrm{A}$ and $\operatorname{cop} \mathrm{C}$ encode for periplasmic proteins, whereas $\operatorname{cop} \mathrm{B}$ and $c o p \mathrm{D}$ encode for outer and inner membrane proteins, respectively. In a combined effort, these proteins function to sequester copper in the periplasm and outer membrane.

Other heavy metals disrupt the plasma membranes in many cell types $(2,29,30)$. A number of studies with higher plants have demonstrated that changes in cell membranes occur when exposed to copper or other heavy metals $(35,47,57)$. Our results support the work of Frostegard et al. (20) and Pennanen et al. (50) that changes in fatty acid composition occur in bacteria exposed to copper or other heavy metals. Changes in fatty acid composition probably reflect changes in cell membrane structure which, in turn, are related to the mode of action of copper tolerance.

\section{ACKNOWLEDGMENTS}

Funding for this research was provided by USDA/CSREES Grant No. 99-34389-7437, titled "Integrated Disease Management to Improve the Quality of Sweet Onions in Georgia."

\section{LITERATURE CITED}

1. Adaskaveg, J. E., and Hine, R. B. 1985. Copper tolerance and zinc sensitivity of Mexican strains of Xanthomonas campestris pv. vesicatoria, causal agent of bacterial spot of pepper. Plant Dis. 70:993-997.

2. Avery, S. V., Howlett, N. G., and Radice, S. 1996. Copper toxicity towards Saccharomyces cerevisiae: Dependence on plasma membrane fatty acid composition. Appl. Environ. Microbiol. 62:3960-3966.

3. Azad, H. R., Holmes, G. J., and Cooksey, D. A. 2000. A new leaf blotch disease of sudangrass caused by Pantoea ananas and Pantoea stewartii. Plant Dis. 84:973-979.

4. Baird, R. E., Gitaitis, R. D., Carling, D. E., Baird, S. M. J., Alt, P. J., and Mullinix, B. G. 2000. Determination of whole-cell fatty acid profiles for the characterization and differentiation of isolates of Rhizoctonia solani AG-4 and AG-7. Plant Dis. 84:785-788.

5. Basim, H., Minsavage, G. V., Stall, R. E., Wang, J-F., Shanker S., and Jones, J. B. 2005. Characterization of a unique chromosomal copper resistance gene cluster from Xanthomonas campestris pv. vesicatoria. Appl. Environ. Microbiol. 71:8284-8291.

6. Bird, N. P., Chambers, J. G., Leech, R. W., and Cummins, D. 1985. A note 
on the use of metal species in microbiological tests involving growth media. J. Appl. Bacteriol. 59:353-355.

7. Birnbaum, D., Herwaldt, L., Low, D. E., Noble, M., Pfaller, M., Sherertz, R., and Chow, A.W. 1994. Efficacy of microbial identification system for epidemiologic typing of coagulase-negative Staphylococci. J. Clin. Microbiol. 32:2113-2119.

8. Bruton, B. D., Wells, J. M., and Lester, G. E. 1986. Pathogenicity of Erwinia ananas to muskmelons in Texas. (Abstr.) Phytopathology 76:1136.

9. Bruton, B. D., Wells, J. M., Lester, G. E., and Patterson, C.L. 1991. Pathogenicity and characterization of Erwinia ananas causing a post harvest disease of cantaloupe fruit. Plant Dis. 75:180-183.

10. Carpenter-Boggs, L., Kennedy, A. C., and Reganold, J. P. 1998. Use of phospholipid fatty acids and carbon source utilization patterns to track microbial community succession in developing compost. Appl. Environ. Microbiol. 64:4062-4064.

11. Cervantes, C., and Gutierrez-Corona, F. 1994. Copper resistance mechanisms in bacteria and fungi. FEMS Microbiol. Rev. 14:121-138.

12. Conlin, K. C., and McCarter, S. M. 1983. Effectiveness of selected chemicals in inhibiting Pseudomonas syringae pv. tomato in vitro and in controlling bacterial speck. Plant Dis. 67:639-644.

13. Cooksey, D. A. 1990. Genetics of bactericide resistance in plant pathogenic bacteria. Annu. Rev. Phytopathol. 28:201-219.

14. Cooksey, D. A. 1994. Molecular mechanisms of copper resistance and accumulation in bacteria. FEMS Microbiol. Rev. 14:381-386.

15. Coutinho, T. A., Preisig, O., Mergaert, J., Cnockaert, M. C., Riedel, K. H., Swings, J., and Wingfield, M. J. 2002. Bacterial blight and dieback of Eucalyptus species, hybrids, and clones in South Africa. Plant Dis. 86:2025

16. Crossan, D. F., Morehart, A. L., Baniecki, J. F., and Biehn, W. 1963. A comparison of fixed copper and dodine sprays with various additives for control of bacterial spot of pepper fruit. Plant Dis. Rep. 47:239-240.

17. Dickens, L. E., and Oshima, N. 1968. An evaluation of protective sprays for halo blight control in snap beans. Plant Dis. Rep. 52:225-226.

18. Dookun, A., Stead, D. E., and Autrey, L. J. C. 2000. Variation among strains of Xanthomonas campestris pv. vasculorum from Mauritius and other countries based on fatty acid analysis. Syst. Appl. Microbiol. 23:148-155.

19. Elliott, C. 1951. Manual of Bacterial Plant Pathogens, 2nd ed. Chronica Botanica, Waltham, MA

20. Frostegard, A., Tunlid, A., and Baath, E. 1993. Phopholipid fatty acid composition, biomass, and activity of microbial communities from two soil types experimentally exposed to different heavy metals. Appl. Environ. Microbiol. 59:3605-3617.

21. Gitaitis, R. D., and Beaver, R. W. 1990. Characterization of fatty acid methyl ester content of Clavibacter michiganensis subsp. michiganensis. Phytopathology 80:318-321.

22. Gitaitis, R. D., and Gay, J. D. 1997. First report of a leaf blight, seed stalk rot, and bulb decay of onion by Pantoea ananas in Georgia. Plant Dis. 81:1096.

23. Gitaitis, R. D., Sanders, F. H., Diaz-Perez, J. C., and Walcott, R. R. 2003. Integrated management of bacterial streak and bulb rot of onion. Pages 443-449 in: Pseudomonas syringae and Related Pathogens: Biology and Genetics. N. S. Iacobellis, A. Collmer, S. W. Hutcheson, J. W. Mansfield, C. E. Morris, J. Murillo, N. W. Schaad, D. E. Stead, G. Surico, and M. S. Ullrich, eds. Kluwer Academic Publishers, Dordrecht, The Netherlands.

24. Gitaitis, R., Walcott, R., Culpepper, S., Sanders, H., Zolobowska, L., and Langston, D. 2002. Recovery of Pantoea ananatis, causal agent of center rot of onion, from weeds and crops in Georgia, USA. Crop Prot. 21:983989.

25. Gitaitis R. D., Walcott, R. R., Sanders, H. F., Zolobowska, L., and DiazPerez, J. C. 2004. Effects of mulch and irrigation system on sweet onion: II. The epidemiology of center rot. J. Am. Hortic. Soc. 129:225-230.

26. Gitaitis, R. D., Walcott, R. R., Wells, M. L., Diaz Perez, J. C., and Sanders, F. H. 2003. Transmission of Pantoea ananatis, causal agent of center rot of onion, by tobacco thrips, Frankliniella fusca. Plant Dis. 87:675-678.

27. Gupta, S. D., Lee, B. T. O., Camakaris, J., and Wu, H. C. 1995. Identification of $c u t C$ and $c u t F(n l p E)$ genes involved in copper tolerance in Escherichia coli. J. Bacteriol. 177:4207-4215.

28. Hattingh, M. J., and Walters, D. F. 1981. Stalk and leaf necrosis of onion caused by Erwinia herbicola. Plant Dis. 65:615-618.

29. Howlett, N. G., and Avery, S. V. 1997. Induction of lipid peroxidation during heavy metal stress in Saccharomyces cerevisiae and influence of plasma membrane fatty acid unsaturation. Appl. Environ. Microbiol. 63:2971-2976.

30. Howlett, N. G., and Avery, S. V. 1997. Relationship between cadmium sensitivity and degree of plasma membrane fatty acid unsaturation in Saccharomyces cerevisiae. Appl. Microbiol. Biotechnol. 48:539-545.

31. Keitt, G. W. 1959. History of plant pathology. Pages 61-97 in: The
Diseased Plant, Plant Pathology, An Advanced Treatise, Vol. 1. J. G. Horsfall and A. E. Dimond, eds. Academic Press. New York.

32. Langston, D. B., Jr., and Cummings, M. P. 2004. Evaluation of bactericides and plant defense activators for control of black rot of cabbage, 2003. Fungic. Nematicide Tests 59:V111.

33. Leonard, R. B., Mayer, J., Sasser, M., Woods, M., Mooney, B. R., Brinton, B. G., Newcomb-Gayman, P. L., and Carroll, K. C. 1995. Comparison of MIDI Sherlock system and pulsed-field gel electrophoresis in characterizing strains of methicillin-resistant Staphylococcus aureus from a recent hospital outbreak. J. Clin. Microbiol. 33:2723-2727.

34. Lim, W. H. 1986. Bacterial diseases of pineapple. Rev. Trop. Plant Pathol. 2:127-140.

35. Maksymiec, W., Russa, R., Urbanik-Sypniewska, T., and Baszynski, T. 1992. Changes in acyl lipid and fatty acid composition in thylakoids of copper non-tolerant spinach exposed to excess copper. J. Plant Physiol. 140:52-55.

36. Marco, G. M., and Stall, R. E. 1983. Control of bacterial spot of pepper initiated by strains of Xanthomonas campestris pv. vesicatoria that differ in sensitivity to copper. Plant Dis. 67:779-781.

37. Martin, H. L., Hamilton, V. A., and Kopittke, R. A. 2004. Copper tolerance in Australian populations of Xanthomonas campestris pv. vesicatoria contributes to poor field control of bacterial spot of pepper. Plant Dis. 88:921-924.

38. Menkissoglu, O., and Lindow, S. E. 1991. Relationship of free ionic copper and toxicity to bacteria in solution of organic compounds. Phytopathology 81:1258-1263.

39. Mergaert, J., Verdancy, L., and Keister, K. 1993. Transfer of Erwinia ananas (synonym, Erwinia uredovora) and Erwinia stewartii to the genus Pantoea emend. as Pantoea ananas (Serrano 1928) comb. nov. and Pantoea stewartii (Smith 1898) comb. nov., respectively, and description of Pantoea stewartii subsp. indologenes subsp. nov. Int. J. Syst. Bacteriol. 43:162-173.

40. Miller, S. A., Ivey, M. L. L., and Mera, J. R. 2004. Evaluation of products to control bacterial foliar and fruit diseases of tomatoes, 2003. Fungic. Nematicide Tests 59:V020.

41. Mirza, M. S., Janse, J. D., Hahn, D., and Akkermans, A. D. L. 1991. Identification of atypical Frankia strains by fatty acid analysis. FEMS Microbiol. Ecol. 33:129-137.

42. Nies, D. H. 1999. Microbial heavy-metal resistance. Appl. Microbiol. Biotechnol. 51:730-750.

43. Nordberg, J., and Arner, E. S. J. 2001. Reactive oxygen species, antioxidants, and the mammalian thioredoxin system. Free Rad. Biol. Med. $31: 1287-1312$.

44. Norton, C. D., and LeChevallier, M. W. 2000. A pilot study of bacteriological population changes through potable water treatment and distribution. Appl. Environ. Microbiol. 66:268-276.

45. Obradovic, A., Mavridis, A., Rudolph, K., Janse, J. D., Arsenijevic, M., Jones, J. B., Minsavage, G. V., and Wang, J-F. 2004. Characterization and PCR-based typing of Xanthomonas campestris pv. vesicatoria from peppers and tomatoes in Serbia Eur. J. Plant Pathol. 110:285-292.

46. Olson, B. D., and Jones, A. L. 1983. Reduction of Pseudomonas syringae pv. morsprunorum on Montmorency sour cherry with copper and dynamics of the copper residues. Phytopathology 73:1520-1525.

47. Ouariti, O., Boussama, N., Zarrouk, M., Cherif, A., and Ghorbal, M. H. 1997. Cadmium- and copper-induced changes in tomato membrane lipids. Phytochemistry 45:1343-1350.

48. Outten, F. W., Huffman, D. L., Hale, J. A., and O'Halloran, T. V. 2001. The independent cue and cus systems confer copper tolerance during aerobic and anaerobic growth in Escherichia coli. J. Biol. Chem. 276:30670-30677.

49. Pankhurst, C. E., Yu, S., Hawke, B. G., and Harch, B. D. 2001. Capacity of fatty acid profiles and substrate utilization pattern to describe differences in soil microbial communities associated with increased salinity or alkalinity at three locations in South Australia. Biol. Fertil. Soils 33:204-217.

50. Pennanen, T., Frostegard, A., Fritze, H., and Baath, E. 1996. Phospolipid fatty acid composition and heavy metal tolerance of soil microbial communities along two heavy metal-polluted gradients in coniferous forests. Appl. Environ. Microbiol. 62:420-428.

51. Pernezny, K., Kudela, V., Kokoskova, B., and Hladka, I. 1995. Bacterial diseases of tomato in the Czech and Slovak Republics and lack of streptomycin resistance among copper-tolerant bacterial strains. Crop Prot. 14:267-270.

52. Pon, D. S., Townsend, C. E., Wessman, G. E., Schmitt, C. G., and Kingsolver, C. H. 1954. A Xanthomonas parasitic on uredia of cereal rusts. Phytopathology 44:707-710.

53. Pscheidt, J. W., and Bassinette, J. P. 2006. Bactericides for control of bacterial blight of lilac, 2005. Fungic. Nematicide Tests 61:OT031.

54. Ritchie, D. F., and Dittapongpitch, V. 1991. Copper- and streptomycinresistant strains and host-differentiated races of Xanthomonas campestris 
pv. vesicatoria in North Carolina. Plant Dis. 75:733-736.

55. Roberts, P. D., Hodge, N. C., Bouzar, H., Jones, J. B., Stall, R. E., Berger, R. D., and Chase, A. R. 1998. Relatedness of strains of Xanthomonas fragariae by restriction fragment length polymorphism, DNA-DNA reassociation, and fatty acid analyses. Appl. Environ. Microbiol. 64:39613965.

56. Scheck, H. J., Pscheidt, J. W., and Moore, L. W. 1996. Copper and streptomycin resistance in strains of Pseudomonas syringae from Pacific Northwest nurseries. Plant Dis. 80:1034-1039.

57. Smith, K. L., Bryan, G. W., and Harwood, J. L. 1985. Changes in endogenous fatty acids and lipid synthesis associated with copper pollution in Fucus spp. J. Exp. Bot. 36:663-669.

58. Stall, R. E. 1959. An evaluation of spray materials for control of bacterial spot on field seeded tomatoes. Plant Dis. Rep. 43:725-728.

59. Stall, R. E., Alexander, L. J., and Hall, C. B. 1969. Effect of tobacco mosaic virus and bacterial infections on occurrence of graywall of tomato. (Erwinia ananas). Proc. Fla. State Hortic. Soc. 81:157-161.

60. Vargas, E., Gutierrez, S., Ambriz, M. E., and Cervantes, C. 1995. Chromosome-encoded inducible copper resistance in Pseudomonas strains. Antonie Leeuwenhoek 68:225-229.

61. Vauterin, L., Yang, P., Alvarez, A., Takikawa, T., Roth, D. A., Vidaver, A. K., Stall, R. E., Kersters, K., and Swings, J. 1996. Identification of nonpathogenic Xanthomonas strains associated with plants. Syst. Appl.
Microbiol. 19:96-105.

62. Verma, P., Leonard, R. B., Lay, M. J., Hillyard, D. H., Brinton, B. G., and Carroll, K. C. 1996. Strain typing of Stenotrophomonas maltophilia by pulsed-field gel electrophoresis, MIDI Sherlock gas chromatography, and ERIC-PCR. Abstr. 96th Annu. Meet. Am. Soc. Microbiol., Washington, D.C.

63. Walcott, R. R., Gitaitis, R. D., Castro, A. C., Sanders, F. H., Jr., and DiazPerez, J. C. 2002. Natural infestation of onion seed by Pantoea ananatis, causal agent of center rot. Plant Dis. 86:106-111.

64. Wells, J. M., Sheng, W. S., Ceponis, M. J., and Chen, T. A. 1987. Isolation and characterization of strains of Erwinia ananas from honeydew melons. Phytopathology 77:511-514.

65. Wells, M. L., Gitaitis, R. D., and Sanders, F. H. 2002. The association of tobacco thrips, Frankliniella fusca, (Thysanoptera: Thripidae) with two species of bacteria of the genus Pantoea. Ann. Entomol. Soc. Am. 95:719723.

66. Wiener, P., Muller-Graf, C., and Barcus, V. 1999. Bacterial evolution in modern times: Trends and implications for research. Integr. Biol. 1:149160.

67. Zelles, L., Bai, Q. Y., Ma, R. X., Rackwitz, R., Winter, K., and Beese, F. 1994. Microbial biomass, metabolic activity and nutritional status determined from fatty acid patterns and poly-hydroxybutyrate in agriculturallymanaged soils. Soil Biol. Biochem. 26:439-446. 